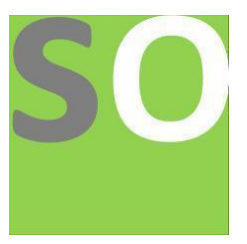

Article title: Review of Toxic Chemicals in Cosmetics

Authors: Domina Petric[1]

Affiliations: Clinical pharmacology and toxicology, University Hospital Center, Soltanska 1, 21000 Split, Croatia[1]

Orcid ids: 0000-0001-5609-1675[1]

Contact e-mail: domina.petric@gmail.com

License information: This work has been published open access under Creative Commons Attribution License http://creativecommons.org/licenses/by/4.0/, which permits unrestricted use, distribution, and reproduction in any medium, provided the original work is properly cited. Conditions, terms of use and publishing policy can be found at https://www.scienceopen.com/.

Preprint statement: This article is a preprint and has not been peer-reviewed, under consideration and submitted to ScienceOpen Preprints for open peer review.

DOI: 10.14293/S2199-1006.1.SOR-.PPKO7OD.v1

Preprint first posted online: 20 October 2021

Keywords: toxicology, cosmetics, toxins 


\title{
Review of Toxic Chemicals in Cosmetics
}

Domina Petric, MD

\begin{abstract}
Aim of this article is to review the literature about toxic chemicals in cosmetics, to emphasize the importance of toxicological research in cosmetology and to support the campaign for safe cosmetics. There is a need for the establishment of higher standards in cosmetology in a way of raising awareness about toxic chemicals that should be avoided, promoting safer cosmetics and transforming cosmetic industry into safe and non-toxic.
\end{abstract}

\section{INTRODUCTION}

Today's life is unimaginable without the use of many cosmetic and cosmeceutical products, some of which have toxic chemicals that should be avoided. The role of toxicology in cosmetic and cosmeceutical industry is to ensure that toxic ingredients are avoided and replaced with less toxic, or even better, non-toxic chemicals. The importance of the campaign for safe cosmetics is to raise awareness about toxic chemicals in cosmetics, promote safety standards and stimulate the transformation of cosmetic industry into safe and non-toxic.

\section{1,4-DIOXANE}

1,4-dioxane, a carcinogen linked to organ toxicity, may be found in as many as 22 percent of the more than 25,000 cosmetic products in the Skin Deep database ${ }^{1}$.
It is not marked on ingredient labels because it is a contaminant produced during manufacturing. It is found in products that create suds such as shampoos, liquid soaps, bubble baths, hair relaxers...

1,4-dioxane is generated through a process called ethoxylation, in which ethylene oxide, a known breast carcinogen, is added to other chemicals to make them less harsh $^{2}$. Research shows that 1,4-dioxane readily penetrates the $\mathrm{skin}^{3}$. It is considered a probable human carcinogen by the U.S. Environmental Protection Agency ${ }^{4}$ and is listed as an animal carcinogen by the National Toxicology Program ${ }^{5}$. It is included on California's Proposition 65 list of chemicals known or suspected to cause cancer or birth defects ${ }^{6}$. 


\section{ACRYLATES}

Acrylates (ethyl acrylate, ethyl methacrylate, and methyl methacrylate) are ingredients found in artificial nail products (acrylic nails, nail enhancing polishes). Inhalation and skin contact are two main exposure routes. Despite evidence of adverse skin, eye, and throat reactions to these chemicals, they continue to be used in nail products ${ }^{2}$.

The International Agency of Research on Cancer (IARC) and U.S. Environmental Protection Agency (EPA) classify ethyl acrylate as a possible human carcinogen ${ }^{7,8}$.

Workers in acrylic sheet manufacturing exposed to both high and low levels of methyl methacrylate (MMA) were at an increased risk of colorectal cancer ${ }^{9}$.

Orthopedic surgeons are chronically exposed to MMA and are proportionately more likely to die from cancer, especially esophageal and myeloproliferative cancers, than general surgeons ${ }^{10}$.

MMA inhalation is toxic to $\operatorname{lungs} \mathrm{s}^{11}$ and is associated with damage to nasal passages, liver, and kidneys ${ }^{12}$. Ethyl acrylate is toxic to the lungs, liver, kidneys, and gastrointestinal system ${ }^{13}$. Two studies showed that occupational exposure to MMA can cause symptoms of generalized and peripheral nerve damage $\mathrm{e}^{14,15}$.
Acrylates are skin, eye, and respiratory tract irritants, and can cause workplaceinduced asthma (occupational exposure) and allergic contact dermatitis (artificial nails that contain acrylates ${ }^{2}$ ).

\section{BENZOPHENONE}

Benzophenone is used in personal care products such as lip balm and nail polish to protect the products from UV light. Derivatives of benzophenone, such as benzophenone-2 (BP2) and oxybenzone (benzophenone-3 or BP3) are common ingredients in sunscreen ${ }^{2}$.

Benzophenone is persistent, bioaccumulative and toxic ${ }^{16,}{ }^{17}$. It is considered to be a possible human carcinogen $^{18}$ and possible endocrine disruptor ${ }^{19}$. The European Food Safety Authority (EFSA) classifies benzophenone as a known toxicant because it can cause liver hypertrophy in the rat at lower doses $^{20}$. Oxybenzone can permeate across the skin and accumulate in blood, kidneys and liver in rats, and may be hepatotoxic ${ }^{21}$.

\section{BUTYLATED COMPOUNDS}

Butylated hydroxyanisole (BHA) and butylated hydroxytoluene (BHT) are used as preservatives in a variety of personal care products (lip and hair products, makeup, sunscreen, antiperspirants, deodorants, fragrances, creams ${ }^{2}$ ). 
According to European Commission on Endocrine Disruption there is strong evidence that BHA is a human endocrine disruptor. A study carried out in normal mammalian kidney cells found that exposure to BHA caused specific damage at the cellular level and was found to exert a significant cytotoxic effect even at low doses $^{22}$. IARC determined that there was only limited evidence of carcinogenicity for products used on the lips. There is moderate evidence that BHT is a human respiratory irritant ${ }^{2}$.

\section{CARBON BLACK}

Carbon black is a dark black powder used as a pigment in cosmetics such as eyeliner, mascara, lipstick, nail polish, eye shadow, brush-on-brow, blushers, rouge, makeup and fundation ${ }^{2}$.

IARC classifies carbon black as possible human carcinogen. Several human studies indicate carbon black exposure may increase the risk of lung disease ${ }^{23}$.

Data from the study on rats conducted by Kim and coworkers showed that carbon black exposure enhanced the cardiovascular risk by inducing hyperhomocysteinemia and platelet hyperactivity, although these effects may be variable depending on particle size and exposure duration. Homocysteine may be a potential biomarker for cardiovascular toxicity following carbon black exposure ${ }^{24}$.

\section{COAL TAR}

Coal tar is a known human carcinogen found in shampoos and scalp treatments, soaps, hair dyes and lotions ${ }^{2}$.

Occupational exposure to coal tar or coaltar pitch increases the risk of skin cancer. Other types of cancer (lung, bladder, kidney and digestive tract cancer) have also been linked to occupational exposure to coal tar and coal-tar pitch ${ }^{25}$.

Pyridine, a coal tar constituent, has been linked to neurological damage. Effects include emotional and sleep disturbances, as well as loss of coordination ${ }^{26,27}$.

\section{ETHANOLAMINE COMPOUNDS}

Ethanolamine compounds are present in soaps, shampoos, hair conditioners and dyes, lotions, shaving creams, paraffin and waxes, household cleaning products, pharmaceutical ointments, eyeliners, mascara, eye shadows, blush, make-up bases, foundations, fragrances, and sunscreens. The European Commission prohibits diethanolamine (DEA) in cosmetics, to reduce contamination from carcinogenic nitrosamines that are formed after the reaction of DEA with other ingredients ${ }^{2}$. 
DEA and TEA (triethanolamine) have been found to be hepatocarcinogenic in female mice $^{28,29}$. Studies have found that DEA affects human male reproductive health. It alters sperm structure, causing abnormalities that affect the sperm's ability to swim and fertilize the $\mathrm{egg}^{30}$.

DEA accumulates in the liver and kidney, causing organ toxicity. It has also possible neurotoxic effects such as tremor ${ }^{31}$. Another study suggests that memory function and brain development in offspring could be permanently affected by mothers' exposure to DEA ${ }^{32}$.

\section{ETHOXYLATED INGREDIENTS}

Ethoxylated ingredients are found in shampoo, liquid soap, bubble bath and hair relaxers $^{2}$. Ethoxylated ingredients are generally of low concern on their own, but they can be contaminated with ethylene oxide, a known human carcinogen. Lymphoma and leukemia are the cancers most frequently reported to be associated with occupational exposure to ethylene oxide, but stomach and breast cancers may also be associated with it $^{33}$.

\section{FORMALDEHYDE}

Formaldehyde and formaldehyde-releasing preservatives are found in nail polish, nail glue, eyelash glue, hair gel, hair-smoothing products, baby shampoos, body soaps, body wash, and color cosmetics ${ }^{2}$.

Formaldehyde is a known human carcinogen. Studies of workers exposed to high levels of formaldehyde, such as industrial workers and embalmers, have found that formaldehyde causes myeloid leukemia, and cancers of the paranasal sinuses, nasal cavity and nasopharyn ${ }^{34}$.

Formaldehyde is also the 2015 American Contact Dermatitis Society contact allergen of the year ${ }^{35}$.

\section{FRAGRANCE}

The International Fragrance Association (IFRA) lists 3,059 materials that are reported as being used in fragrance compounds. Of these 3,059 ingredients, some (such as acetaldehyde, benzophenone, BHA, BHT, benzyl salicylate, benzyl benzoate, butoxyethanol, butylphenyl methylpropional, methyl chloride, methylene chloride, diethyl phthalate, essential oil mixtures, methyleugenol, formaldehyde, ethanolamines, methanol, oxybenzone, propyl paraben, resorcinol, styrene, synthetic musks, titanium dioxide, 1,4dioxane, ethylbenzene and vinyl acetate) have evidence linking them to health effects including cancer, reproductive toxicity, allergies and sensitivities ${ }^{2,36}$. 


\section{HOMOSALATE}

Homosalate is a widely used chemical in sunscreens and skin care products with sun protecting factor $(\mathrm{SPF})$. It is a potential endocrine disruptor (impacts androgen and progesterone systems) and it may enhance the absorption of pesticides in the body ${ }^{2}$.

In human breast cancer cells homosalate exposure led to 3.5 times more cell growth and multiplication ${ }^{37}$.

\section{HYDROQUINONE}

Hydroquinone is most commonly used in skin lighteners, products heavily marketed towards women of color. It is also found in skin lighteners, facial and skin cleansers, facial moisturizers, hair conditioners, and finger nail coating products ${ }^{2}$.

Hydroquinone decreases the production and increases the degradation of melanin pigments in the skin, what increases the skin's exposure to UVA and UVB rays, and the consequence is increased risk of skin cancer ${ }^{38}$. Hydroquinone is linked to a skin condition called ochronosis in which the skin thickens and turns bluish-grey ${ }^{39}$. Exposure of the eye can cause pigmentation and permanent corneal damage $^{40}$. Hydroquinone may be harmful if inhaled, causing irritation of the nose, throat and upper respiratory tract.
A study on occupational exposure of hydroquinone showed that subjects exposed to hydroquinone had a higher prevalence of cough and decreased lung capacity compared to their unexposed counterparts $^{41}$.

\section{HEAVY METALS}

Heavy metals like lead, arsenic, mercury, aluminum, zinc, chromium and iron are found in a wide variety of personal care products including lipsticks, whitening toothpaste, eyeliners, nail colors, foundations, sunscreens, eye shadows, blushes, concealers, moisturizers, and eye drops $^{2}$. Lead is a well-known and proven neurotoxin that has been linked to learning, language and behavioral problems ${ }^{42}$.

Lead has been linked to reduced fertility in $\operatorname{men}^{43}$ and women ${ }^{44}$, hormonal changes and menstrual irregularities. Pregnant women are especially vulnerable because lead crosses the placenta and may enter the fetal brain, and has also been linked to miscarriage $^{45}$.

Mercury is linked to nervous system toxicity, as well as reproductive, immune and respiratory toxicity, and is a recognized environmental health concern by numerous national and international government bodies ${ }^{46}$. Mercury may also disrupt thyroid hormones ${ }^{47}$. 
Aluminum-based compounds vary in their toxicity, but some are linked to neurotoxicity, developmental and reproductive toxicity, and cancer ${ }^{48}$.

Excess chromium levels (chromium is an essential trace element in human body, it is important factor for enhancing insulin activity) are strongly linked to immune and respiratory toxicity, as well as systemic toxicity ${ }^{49}$.

\section{MIT, CMIT}

Methylisothiazolinone (MIT) and methylchloroisothiazolinone (CMIT) are found in shampoos, conditioners, hair colors, body wash, lotions, sunscreens, mascaras, shaving creams, baby lotions, baby shampoos, hairsprays, makeup removers, liquid soaps and detergents ${ }^{2}$.

Rats exposed to highly concentrated MIT (over $50 \%$ ) showed a range of symptoms, including significant body weight gain and death. Autopsies revealed that death was due to reddened lungs and swollen intestines $^{50}$. MIT and CMIT are two of the most predominant contact allergens found in cosmetic products ${ }^{51}$.

In vitro cell studies on MIT showed signs of neurotoxicity when cerebral cortex cells were exposed to liquid $\mathrm{MIT}^{52}$.

\section{MICA}

Mica is a naturally occurring mineral dust often used in makeup foundations, as filler in cement and asphalt, and as insulation material in electric cables ${ }^{2}$. Mica is a respiratory irritant. Long-term inhalation of mica dust may cause lung scarring which leads to symptoms such as coughing, shortness of breath, weakness, and weight $\operatorname{loss}^{53}$.

\section{NAIL POLISH REMOVERS}

Isopropyl acetone, methyl ethyl ketone, and n-methyl-pyrrolidone, are commonly used as the solvent in nail polish removers. These chemicals are skin, eyes and respiratory irritants. There is some evidence about possible carcinogenicity of isopropyl acetone ${ }^{2}$.

\section{NANOPARTICLES}

Insoluble nanoparticles in cosmetic products are essentially used as UV-filters or preservatives. Nanoparticles can be found in deodorants, toothpastes, shampoos, lotions, foundation, anti-aging creams, and nail polish ${ }^{2}$.

Studies have indicated that low solubility nanoparticles (such as titanium dioxide, zinc oxide, silver, fullerenes, silica, carbon black) tend to be more toxic than larger particles of the same material ${ }^{54}$. 
Inhalation of nanomaterials may lead to inflammation and oxidative stress ${ }^{55-57}$.

\section{NITROSAMINES}

Nitrosamines can be found in nearly every kind of personal care product. Nitrosamines are probable human carcinogens (group 2A). There is also some evidence of endocrine disruption at very low doses ${ }^{2}$. N-nitrosodiethanolamine, one form of nitrosamine, accumulates in the liver, bladder and other organs and leads to chronic toxic health effects ${ }^{58}$.

\section{OCTINOXATE}

Octinoxate is an UV filter found in hair color products and shampoos, sunscreen, lipsticks, nail polish, and skin creams ${ }^{2}$.

Octinoxate increases cell proliferation in cells that grow in response to estrogen exposure what can increase the risk of breast cancer ${ }^{59}, 60$. Octinoxate can also reduce the level of thyroid hormones in blood serum ${ }^{61}$.

Numerous studies have reported that octinoxate exhibits antiandrogenic activity, which is linked to harmful effects on reproductive organ development in male and female fetuses exposed in utero ${ }^{2}$.

\section{PARABENS}

Parabens are preservatives that can be found in shampoos, conditioners, lotions, facial and shower cleansers and scrubs ${ }^{2}$.

Parabens are potential endocrine disruptors due to their ability to mimic estrogen. Combined with other estrogenic chemicals parabens may potentially influence the development of malignant melanoma through their estrogenic and genotoxic activites $^{62}$. Some studies have also shown that parabens have potential developmental and reproductive toxicity ${ }^{2}$.

\section{PABA}

PABA (para-amino benzoic acid) and PABA derivatives are commonly used in sunscreens as ultraviolet B (UVB) filters ${ }^{2}$.

Studies performed on rats and on thyroid tissue samples suggest that PABA may disrupt thyroid activity ${ }^{63-65}$ by decreasing the levels of thyroxine.

UV radiation is more likely to damage DNA in the presence of PABA, and DNA damage to the skin increases the risk of skin cancer ${ }^{66-68}$.

\section{PETROLATUM}

Petrolatum, or petroleum jelly, derived from petroleum, is often used in personal care products (such as lotions) as moisturizing agent ${ }^{2}$. 
Petrolatum can be contaminated with toxic chemicals called polycyclic aromatic hydrocarbons (PAHs). IARC lists 14 PAHs as probable or possible carcinogens and one PAH as a known carcinogen ${ }^{69}$.

\section{PHENOXYETHANOL}

Phenoxyethanol is used as a preservative in cosmetic products and also as a stabilizer in perfumes and soaps. It can be found in moisturizers, eye shadows, foundation, sunscreens, conditioners, mascaras, eye liners, shampoos, lip gloss, concealers, body wash, hand creams, blush, hair colors, hair sprays, lip balms, lotions, nail polish, baby wipes, baby lotions and soaps, soap (liquid and bar), shaving creams, deodorants, toothpaste, fragrance, hair removal waxes, hand sanitizer and ultrasound gel $^{2}$. Exposure to phenoxyethanol has been linked to reactions ranging from eczema ${ }^{70}$ to severe, life-threatening allergic reactions ${ }^{71}$.

Infant oral exposure to phenoxyethanol can acutely affect nervous system function ${ }^{72}$.

\section{POLYACRYLAMIDE}

Polyacrylamide is used as a stabilizer and binder in lotions and other products. It can be found in facial moisturizers, anti-aging products, color cosmetics, lotions, hair products, and sunscreens. Polyacrylamide can break down into acrylamide, which is a probable human carcinogen, and can be associated with reproductive and developmental toxicity ${ }^{2}$.

\section{POLYTETRAFLUOROETHYLENE (PTFE, TEFLON)}

Polytetrafluoroethylene can be found in foundation, pressed powder, loose powder, bronzer, blush, eye shadow, mascara, shave gel, lip balm, and anti-aging lotion ${ }^{2}$.

These products can be contaminated with perfluorooctonoic acid (PFOA) that is a possible human carcinogen (IARC).

PFOA exerts effects on the endocrine system, disrupting estrogen receptors, thyroid receptors, steroid hormones, and male testosterone levels ${ }^{73-75}$.

PFOA has also been linked to delayed puberty in girls, reproductive toxicity and inflammation ${ }^{2}$.

\section{P-PHENYLENEDIAMINE}

P-phenylenediamine can be found in many forms of permanent hair dyes called oxidative dyes ${ }^{2}$. German study showed that p-phenylenediamine was the fifth most common skin allergen and that it had about a $5 \%$ sensitization rate $^{76}$.

When p-phenylenediamine reacts with hydrogen peroxide, as it does in the preparation of hair dyes, it can form a mutagenic substance called Bandrowski's 
base, which has been shown to be strongly mutagenic and possibly carcinogenic ${ }^{77,78}$.

When ingested, p-phenylenediamine is highly toxic. Often referred to as hair dye poisoning, it can cause respiratory distress and renal failure ${ }^{78,79}$.

\section{PHTHALATES}

Phthalates have been banned from cosmetics in the European Union, but still remain prevalent in U.S. products such as color cosmetics, fragranced lotions, body washes and hair care products, nail polish and treatment. These chemicals are linked to endocrine disruption, developmental and reproductive toxicity, and possibly to cancer $^{2}$.

\section{QUATERNIUM-15}

Quaternium-15 can be found in hair conditioners, hair styling products, creams, lotions, cleansers, shaving products, eye drops contact solutions and household cleaning products ${ }^{2}$. It is a known human skin toxicant, allergen and possible eye $\operatorname{irritant}^{80}$. It is also a formaldehydereleasing preservative, and formaldehyde is known human carcinogen (IARC).

\section{STYRENE}

ACRYLATES

\section{COPOLYMERS}

Styrene acrylates copolymer and related styrene-based polymers are most often found in nail polish, sunscreen (SPF greater than 30), sunscreen moisturizers, body wash/cleansers, shampoos and eyeliners. These products can be contaminated with styrene which is possible human carcinogen ${ }^{2}$.

The European Commission on Endocrine Disruption classifies styrene as a Category 1 endocrine disruptor ${ }^{81}$. Short-term exposure to styrene in humans results in mucous membrane and eye irritation, and adverse gastrointestinal effects. Long-term exposure can cause headache, fatigue, weakness, depression, CSN dysfunction, hearing loss, and nerve damage ${ }^{82,83}$.

\section{RESORCINOL}

Resorcinol is commonly used in hair dyes and acne medication. In higher doses it is toxic and can disrupt the function of the central nervous system (convulsions are reported in acute intoxication) and lead to respiratory problems (respiratory failure in acute intoxication). It has also been shown that resorcinol can disrupt the thyroid function. It has been shown to have two different effects: the inhibition of enzymes involved in thyroid hormone synthesis (leading to hypothyroidism) and the activation of thyroid hormone receptors ${ }^{2}$. 
A study of resorcinol's effects on cells, suggests that resorcinol acts like thyroid hormone and as an agonist at thyroid hormone receptors at low doses ${ }^{84}$.

\section{RETINOL}

Retinol is the chemical name of the essential micronutrient vitamin A that can be found in anti-aging creams and lotions, moisturizers, and foundation ${ }^{2}$.

Retinoic acid and retinyl palmitate, in combination with sunlight, may increase skin cancer risk ${ }^{85}$. The California EPA's Proposition 65 list identifies all-trans retinoic acid as a developmental toxicant ${ }^{2}$.

\section{SYNTHETIC MUSKS}

Synthetic musks can be found in perfumes, colognes, and scented soaps, body wash, sprays, lotions, hair products, detergents, and softeners ${ }^{2}$.

Musk ketone, galaxolide and tonalide alter estrogen activity. Both tonalide and galaxolide inhibit androgen and progesterone from binding to their receptors ${ }^{86,87}$. Musk ketone, musk xylene, and tonalide have also increased the growth and multiplication of estrogenresponsive human breast cells ${ }^{88}$.

High levels of musk xylene and musk ketone in women's blood may be associated with gynecological abnormalities such as ovarian failure and infertility ${ }^{89}$.

\section{TALC}

Talc is found in baby powder, body and shower products, lotions, feminine hygiene products, eyeshadow, foundation, lipstick, deodorants and face masks. Some talc may contain the known human carcinogen asbestos that can cause mesothelioma. IARC classified perineal use of talc as possibly carcinogenic (it might be associated with endometrial and ovarian cancer $^{2,90}$ ).

\section{TITANUM DIOXIDE}

Titanium dioxide is used in a variety of personal care products, including sunscreens, pressed powders, and loose powders, as an UV filter or whitening agent. Inhalable titanium dioxide (in powders) is considered to be possible human carcinogen by IARC ${ }^{2}$.

\section{TOLUENE}

Toluene is a toxic chemical used in nail products and hair dyes. Exposure to toluene can result in temporary effects such as headaches, dizziness and cracked skin, as well as more serious effects such as reproductive damage and respiratory complications $^{2,91}$. 


\section{TRICLOSAN}

Triclosan and triclocarban are commonly used antimicrobial agents found in antibacterial soaps and detergents, toothpaste and tooth whitening products, antiperspirants, deodorants, shaving products, creams, and color cosmetics ${ }^{2}$.

A 2009 study found that triclosan decreased thyroid hormone concentrations $^{92}$. Another study showed that triclosan enhanced the expression of androgen and estrogen sensitive genes ${ }^{93}$.

There is also some evidence linking the use of triclosan with the promotion of bacteria that are resistant to antibiotic medications and antibacterial products ${ }^{94,95}$.

\section{CONCLUSION}

There is a need for the establishment of higher standards in cosmetology in a way of raising awareness about toxic chemicals that should be avoided, promoting safety standards and transforming cosmetic industry into safe and non-toxic. The role of toxicology in cosmetic and cosmeceutical industry is to ensure that toxic ingredients are avoided and replaced with less toxic, or even better, non-toxic chemicals. Therefore, I support the campaign for safe cosmetics.

\section{REFERENCES}

1. Environmental Working Group (2007). Impurities of Concern in Personal Care Products. Retrieved from http://www.cosmeticsdatabase.com (cited on October 19, 2021)

2. Chemicals of concern. Campaign for safe cosmetics. Retrieved from http://www.safecosmetics.org/get-the-facts/chemof-concern/ (cited on October 19, 2021)

3. Spath DP. 1,4-Dioxane Action Level. March 24, 1998. Memorandum. Viewed at http://www.oehha.ca.gov/water/pals/pdf/PAL14DI OXAN.pdf

4. Environmental Protection Agency (2003). 1,4 Dioxane (CASRN 123-91-1). Integrated Risk Information System. Retrieved from http://www.epa.gov/NCEA/iris/subst/0326.htm.

(cited on October 19, 2021)

5. National Toxicology Program. Report on Carcinogens, 11th Edition; U.S. Department of Health and Human Services, Public Health Service, National Toxicology Program, January 2005.

Viewed at http://ntp.niehs.nih.gov/ntp/roc/eleventh/profiles/s0 80diox.pdf.

6. Office of Environmental Health Hazard Assessment (OEHAA) (2004). State of California Environmental Protection Agency. Chemicals known to the state to cause cancer or reproductive toxicity. $\quad$ Retrieved from http://oehha.ca.gov/prop65/prop65_list/files/416041 ist.html. (cited on October 19, 2021)

7. International Agency for Research on Cancer. Ethyl Acrylate. IARC Monographs. 1999;7:14471457. 
8. U.S. Environmental Protection Agency. Ethyl Acrylate. Technology Transfer Network, Air Toxics Web Site, 2013. Retrieved from http://www.epa.gov/ttnatw01/hlthef/ethylacr.html\#r ef2 (cited on October 19, 2021)

9. Tomenson J, Carpenter A, Pemberton M. Critical review of the epidemiology literature on the potential cancer risks of methyl methacrylate. Int Arch Occup Environ Health. 2005;78(8):603-612.

10. Diaz J. Proportionate cancer mortality in methyl methacrylate-exposed orthopedic surgeons compared to general surgeons. J Med Toxicol. 2011;7(2):125-132.

11. Aydin O, Attila G, Dogan A, et al. The effects of methyl methacrylate on nasal cavity, lung, and antioxidant system (an experimental inhalation study). Toxicol Pathol. 2002:30(3):350-356.

12. European Chemicals Bureau. Methyl Methacrylate: European Union Risk Assessment Report. 2002;22:1-180.

13. Center for Disease Control and Prevention. (2014). Ethyl Acrylate. Retrieved from http://www.cdc.gov/niosh/pel88/140-88.html (cited on October 19, 2021)

14. Sadoh D, Sharief M, Howard R. Case study: occupational exposure to methyl methacrylate monomer induces generalized neuropathy in a dental technician. Br Dent J. 1990;186:380-381.

15. Slodownik D, Williams D, Tate B. Prolonged paresthesia due to sculptured acrylic nails. Contact Derm. 2007;56:298-299.

16. Brooks AC, Gaskell PN, Maltby LL. Importance of prey and predator feeding behaviors for trophic transfer and secondary poisoning. Environ Sci Technol. 2009;43(20):7916-7923.
17. Kim S, Choi K. Occurrences, toxicities, and ecological risks of benzophenone-3, a common component of organic sunscreen products: A minireview. Environ Int. 2014;70:143-57.

18. Chemicals Known to the State to Cause Cancer or Reproductive Toxicity. Viewed at http://oehha.ca.gov/prop65/prop65_list/files/P65sin gle01032014.pdf

19. IARC (2012). Benzophenone. Viewed at http://monographs.iarc.fr/ENG/Monographs/vol101 /mono101-007.pdf

20. European Food Safety Authority. EFSA Pannel on food contact materals, enzymes, flavouring and processing aids (CEF). The EFSA Journal. Retrieved from http://www.efsa.europa.eu/en/efsajournal/pub/1104. htm (cited on October 19, 2021)

21. Fediuk DJ. Tissue disposition of the insect repellent DEET and the sunscreen oxybenzone following intravenous and topical administration in rats. Biopharm Drug Dispos. 2011; 32(7):369-79.

22. Labrador V, Fernández Freire P, Pérez Martín JM, Hazen MJ. Cytotoxicity of butylated hydroxyanisole in Vero cells. Cell Biol Toxicol. 2007;23(3):189-99.

23. IARC Monographs on the Evaluation of Carcinogenic Risks to Humans. Carbon Black evaluation and rationale. 2010;93:190-1.

24. Kim H, Oh SJ, Kwak HC, et al. The impact of intratracheally instilled carbon black on the cardiovascular system of rats: evaluation of blood homocysteine and hyperactivity of platelets. $J$ Toxicol Environ Health A. 2012;75(24):1471-83.

25. Coal Tar and Coal-Tar Pitch. National Cancer Institute. December 28, 2018. Retrieved from https:/www.cancer.gov/about-cancer/causes- 
prevention/risk/substances/coal-tar (cited on October 20, 2021)

26. Pirydine. Material Data Safety Sheet. Viewed at http://www.mathesongas.com/pdfs/msds/MAT1999 $0 . p d f$.

27. Pinsky C, Bose R. Pyridine and other coal tar constituents as free radical-generating environmental neurotoxicants. Mol Cell Biochem. 1988;84(2):217-222.

28. Stout MD, Kissling GE, Suárez FA, et al. Influence of Helicobacter hepaticus infection on the chronic toxicity and carcinogenicity of triethanolamine in B6C3F1 mice. Toxicol Pathol. 2008;36(6):783-794.

29. Lehman-McKeeman LD, Gamsky EA, Hicks $\mathrm{SM}$, et al. Diethanolamine induces hepatic choline deficiency in mice. Toxicol Sci. 2002;67(1):38-45.

30. Panchal SR, Verma RJ. Spermatotoxic effect of diethanolamine: An in vitro study. Asian Pac $J$ Reprod. 2013;2(3):196-200.

31. Gamer AO, Rossbacher R, Kaufmann W, van Ravenzwaay B. The Inhalation toxicity of di- and triethanolamine upon repeated exposure. Food Chem Toxicol. 2008;46(6):2173-2183.

32. Craciunescu $\mathrm{CN}$, $\mathrm{Wu} \mathrm{R}$, Zeisel $\mathrm{SH}$. Diethanolamine alters neurogenesis and induces apoptosis in fetal mouse hippocampus. FASEB $J$. 2006;20(10):1635-1640.

33. Ethylene Oxide. National Cancer Institute. December 28, 2018. Retrieved from https://www.cancer.gov/about-cancer/causesprevention/risk/substances/ethylene-oxide (cited on October 20, 2021)

34. Formaldehyde. National Cancer Institute. February 14, 2019. Retrieved from https://www.cancer.gov/about-cancer/causesprevention/risk/substances/formaldehyde (cited on October 20, 2021)

35. Pontén A, Bruze M. Formaldehyde. Dermatitis. 2015;26(1):3-6.

36. IFRA. IFRA Ingredients, 2015. Retrieved from http://www.ifraorg.org/en-us/ingredients\#.VW-

Cdc-6eUk. (cited on October 20, 2021)

37. Jiménez-Díaz I, Molina-Molina JM, ZafraGómez A, et al. Simultaneous determination of the UV-filters benzyl salicylate, phenyl salicylate, octyl salicylate, homosalate, 3-(4-methylbenzylidene) camphor and 3-benzylidene camphor in human placental tissue by LC-MS/MS. Assessment of their in vitro endocrine activity. $J$ Chromatogr B Analyt Technol Biomed Life Sci. 2013;1(936):80-7.

38. Jimbow K, Obata H, Pathak MA, Fitzpatrick TB. Mechanisms of depigmentation by hydroquinone. J Investig Dermatol. 1974;62:436449.

39. Findlay GH, Morrison JGL, Simson IW. Exogenous ochronosis and pigmented colloid milium from hydroquinone bleaching creams. $\mathrm{Br} J$ Dermatol. 1975;93(6):613-622.

40. Naumann G. Corneal damage in hydroquinone workers: a clinicopathologic study. Arch Ophthalmol. 1966;76(2):189-194.

41. Choudat D, Neukirch F, Brochard P, et al. Allergy and occupational exposure to hydroquinone and to methionine. Br J Ind Med. 1988;45(6):376380 .

42. Needleman HL, Schell A, Bellinger D, et al. The long-term effects of exposure to low doses of lead in childhood. An 11-year follow-up report. New Engl J Med. 1990;322(2):83-88. 
43. Wu HM, Lin-Tan DT, Wang ML, et al. Lead level in seminal plasma may affect semen quality for men without occupational exposure to lead. Reprod Biol Endocrinol. 2012;10(1):91.

44. Snijder CA, te Velde E, Roeleveld N, Burdorf A. Occupational exposure to chemical substances and time to pregnancy: a systematic review. Hum Reprod. 2012;18(3):284-300.

45. Agency for Toxic Substances and Disease Registry (ATSDR) (2007). Toxicological profile for Lead. Atlanta, GA: U.S. Department of Health and Human Services, Public Health Service.

46. Agency for Toxic Substances and Disease Registry (ATSDR) (1999). Toxicological profile for mercury. Atlanta, GA: U.S. Department of Health and Human Services, Public Health Service.

47. U.S. EPA (2013). Minimata Convention on Mercury. $\quad$ Retrieved from http://www.epa.gov/international/toxics/mercury/mi namata.html. (cited on October 20, 2021)

48. Agency for Toxic Substances and Disease Registry (ATSDR) (2008). Toxicological profile for Aluminum. Atlanta, GA: U.S. Department of Health and Human Services, Public Health Service. Viewed at http://www.atsdr.cdc.gov/toxprofiles/tp22.pdf

49. Agency for Toxic Substances and Disease Registry (ATSDR) (2012). Toxicological profile for Chromium. Atlanta, GA: U.S. Department of Health and Human Services, Public Health Service. Viewed at http://www.atsdr.cdc.gov/toxprofiles/tp7.pdf.

50. Rohm \& Haas (2002). Acute Inhalation toxicity study in rate (methylisothiazolinone $53.52 \%$ active ingredient). Rohm \& Haas Chemicals, LLC Report, 06R-1002.
51. Lundov MD, Krongaard T, Menné TL, Johansen JD. Methylisothiazolinone contact allergy: a review. $B r \quad J$ Dermatol. 2011;165(6):1178-1182.

52. Burnett CL, Bergfeld WF, Belsito DV, et al. Final report of the safety assessment of methylisothiazolinone. Int J Tox. 2010;29(4):187S213 S.

53. CDC. Occupational Health Guidline for Mica. Viewed at http://www.cdc.gov/niosh/docs/81123/pdfs/0431.pdf

54. CDC: Centers for Disease Control. Nanotechnology. 2016. Retrieved from http://www.cdc.gov/niosh/topics/nanotech/default.h tml (cited on October 20, 2021)

55. Khandoga A, Stampfl A, Takenaka S, et al. Ultrafine particles exert prothrombotic but not inflammatory effects on the hepatic microcirculation in healthy mice in vivo. Circulation. 2004;109(10):1320-1325.

56. Nemmar A, Hoylaerts MF, Nemery B. Effects of particulate air pollution on hemostasis. Clin Occup Environ Med. 2006;5(4):865-81.

57. Bai N, Khazaei M, van Eeden SF, Laher I. The pharmacology of particulate matter air pollutioninduced cardiovascular dysfunction. Pharmacol Ther. 2007;113(1):16-29.

58. Matyaska MT, Pesek JJ, Yang L. Screening method for determining the presence of $\mathrm{N}$ nitrosadiethanolamine in cosmetics by open-tubular capillary electrochromatography. J Chromatogr A. 2000;887:497-503.

59. Darbre PD. Environmental estrogens, cosmetics and breast cancer. Best Pract Res Clin Endocrinol Metabol. 2006;20(1):121-143. 
60. Schlumpf M, Schmid P, Durrer S, et al. Endocrine activity and developmental toxicity of cosmetic UV filters-an update. Toxicology. 2004;205(1):113-122.

61. Boas M, Feldt-Rasmussen U, Main KM. Thyroid effects of endocrine disrupting chemicals. Mol Cell Endocrinol. 2012;335(2):240-248.

62. Darbre PD, Harvey PW. Paraben esters: review of recent studies of endocrine toxicity, absorption, esterase and human exposure, and discussion of potential human health risks. J Appl Toxicol. 2008;28(5):561-78.

63. Astwood EB. The chemical nature of compounds which inhibit the function of the thyroid gland. JPET. 1943;78:179-89.

64. Taurog A, Chaikoff IL, Franklin AL. The structural specificity of sulfanilamide-like compounds as inhibitors of the in vitro conversion of inorganic iodide to thyroxine and diiodotyrosine by thyroid tissue. J Biol Chem. 1945;161:537-43.

65. Taurog A. Thyroid peroxidase and thyroxine biosynthesis. Recent Prog Horm Res. 1970;26:189247.

66. Hodges ND, Moss SH, Davies DJ. The sensitizing effect of a sunscreening agent, paminobenzoic acid on near UV induced damage in a repair deficient strain of Escherichia coli. Photochem Photbiol. 1977;26(5):493-8.

67. Hodges ND, Moss SH, Davies DJ. Elucidation of the nature of genetic damage formed in the presence of the sunscreening agent, para-amino benzoic acid, during irradiation with near ultraviolet light. J Pharm Pharmacol. 1977;29:72.

68. Osgood PJ, Moss SH, Davies DJ. The sensitization of near-ultra violet radiation killing of mammalian cells by the sunscreen agent para- amino benzoic acid. $J$ Invest Dermatol. 1982;79(6):354-7.

69. International Agency for Research on Cancer. (2014). Agents classified by the IARC monographs, vol. 1-112. $\quad$ Retrieved from http://monographs.iarc.fr/ENG/Classification/ (cited on October 20, 2021)

70. Bohn S, Bircher AJ. Phenoxyethanol-induced urticaria. Allergy. 2001;56(9):922-923.

71. Chasset F, Soria A, Moguelet P, et al. Contact dermatitis due to ultrasound gel: A case report and published work review. $J$ Dermatol. 2016;43(3):318-20.

72. U.S. Food and Drug Administration. FDA warns consumers against using Mommy's Bliss Nipple Cream. Retrieved from http://www.fda.gov/NewsEvents/Newsroom/PressA nnouncements/2008/ucm116900.htm. (cited on October 20, 2021)

73. Guizhen $\mathrm{Du}$, Hongyu $\mathrm{H}$, Jialei $\mathrm{Hu}$, et al. Endocrine-related effects of perfluorooctanoic acid (PFOA) in zebrafish, H295R steroidogenesis and receptor reporter gene assays. Chemosphere. 2013;91(8):1099-1106.

74. Manhai L, Mandana G, Bonefeld-Jørgensen C. Effects of perfluoroalkyl acids on the function of the thyroid hormone and the aryl hydrocarbon receptor. Environ Sci Pollut Res Int. 2013;20(11):8045-56

75. Hongxia Z, Yin L, Bin L, et al. Proteomic Analysis of Mouse Testis Reveals Perfluorooctanoic Acid-Induced Reproductive Dysfunction via Direct Distubance of Testicular Steroidogenic Machinery. $J$ Proteome Res. 2014;13(7):3370-85. 
76. Schnuch A, Geier J, Uter PJ, et al. National rates and regional differences in sensitisation to allergens of the standard series. Contact Dermatitis. 1997;37:200-209.

77. Rojanapo W, Kuradinun P, Tepsuwan A, et al. Carcinogenicity of an oxidation product of $\mathrm{p}$ phenylenediamine.

Carcinogenesis. 1986;7(12):1997-2002.

78. Bolt HM, Golka K. The Debate on Carcinogenicity of Permanent Hair Dyes: New Insights. Crit Rev Toxicol. 2007;37:521-536.

79. Anuradha S, Sandeep AS, Arora A, Kar P. Acute Renal Failure Following paraPhenylenediamine (PPD) Poisoning: A Case Report and Review. Renal Failure. 2004;26(3):329-332.

80. EWG's Skin Deep Cosmetics Database. Quaternium-15 Formaldehyde Releaser. Retrieved from

http://www.ewg.org/skindeep/ingredient/705478/Q

UATERNIUM-15/ (cited on October 20, 2021)

81. European Commission. Annex 13. List of 146 substances with endocrine disruption classifications prepared in the Expert meeting. Viewed at http://ec.europa.eu/environment/archives/docum/pd f/bkh_annex_13.pdf.

82. EPA: Environmental Protection Agency. Styrene (2016). Viewed at https://www.epa.gov/sites/production/files/201609/documents/styrene.pdf

83. ATSDR: Agency for Toxic Substances \& Disease Registry. ToxFAQs for Styrene. 2012. Retrieved from http://www.atsdr.cdc.gov/toxfaqs/TF.asp? $\mathrm{id}=420 \& \mathrm{tid}=74($ cited on October 20,2021$)$

84. Ghisari M, Bonefeld-Jorgensen EC. Effects of plasticizers and their mixtures on estrogen receptor and thyroid hormone function. Toxicol Lett. 2009; 189:67-77.

85. NTP report: Photocarcinogenesis study of retinoic acid and retinyl palmitate. August 2012. Viewed at http://ntp.niehs.nih.gov/ntp/htdocs/lt_rpts/tr568_50 8.pdf

86. Witorsch R, Thomas J. Personal care products and endocrine disruption: a critical review of the literature. Crit Rev Toxicol. 2010;40(S3):1-30.

87. Schreurs R, Sonneveld E, Jansen J, et al. Interaction of polycyclic musks and UV filters with the estrogen receptor (ER), androgen receptor (AR), and progesterone receptor $(\mathrm{PR})$ in reporter gene bioassays. Toxicol Sci. 2005;83:264-272.

88. Bitsch N, Dudas C, Körner W, et al. Estrogenic activity of musk fragrances detected by the Escreen assay using human mef-7 cells. Arch Environ Contam Toxicol. 2002;43(3):257-64.

89. Eisenhardt S, Runnebaum B, Bauer K, Gerhard I. Nitromusk compounds in women with gynecological and endocrine dysfunction. Environ Res. 2001;87:123-130.

90. IARC. Agents classified by the IARC Monographs, Volumes 1-112, 2015. Viewed at http://monographs.iarc.fr/ENG/Classification/Classi ficationsAlphaOrder.pdf

91. OSHA, OSHA Infosheet. Viewed at http://www.osha.gov/Publications/OSHA3646.pdf.

92. Zorrilla L, Gibson EK, Jeffay SC, et al. The effects of Triclosan on Puberty and Thyroid Hormones in Male Wistar Rats. Toxicol Sci. 2009; 107(1):56-64.

93. Ahn $\mathrm{KC}$, Zhao B, Chen J, et al. In vitro biologic activities of the antimicrobials triclocarban, its 
analogs, and triclosan in bioassay screens: receptorbased bioassay screens. Environ Health Perspect. 2008;116(9):1203-10.

94. Heath R, Li J, Roland GE, Rock CO. Inhibition of Staphylococcus aureus NADPH-dependent enoyl-acyl carrier protein reductase by triclosan and hexachlorophene. J Biol Chem. 2000;275(7):4654-9.

95. Aiello AE, Marshall B, Levy SB, et al. Antibacterial Cleaning Products and Drug Resistance. Emerg Infect Dis. 2005;11(10):15651570 . 